\title{
Analisis Perbandingan Tax Amnesty Jilid I dan Jilid II (Program Pengungkapan Sukarela) Serta Peluang Keberhasilannya
}

\author{
${ }^{1)}$ Uswatun Hasanah*, ${ }^{2)}$ Khairun Na'im, ${ }^{3)}$ Elyani, ${ }^{4)}$ Khamo Waruwu \\ ${ }^{12,3)}$ Universitas Tjut Nyak Dhien \\ ${ }^{1)}$ uswah.hana@yahoo.com, ${ }^{2)}$ khairun.naim@gmail.com, ${ }^{3)}$ lilyelyani12@gmail.com, \\ 4)wilakstonodimaz@yahooo.co.id
}

$\begin{array}{ll}\text { *Penulis Korespondensi } \\ \text { Diajukan } & : 25 \text { Nopember } 2021 \\ \text { Disetujui } & : 7 \text { Desember } 2021 \\ \text { Dipublikasi } & : 8 \text { Desember } 2021\end{array}$

ABSTRACT

The government has implemented the tax amnesty volume I in July 2016 and ended in March 2017. In early 2022, the government will plan to implement the tax amnesty volume II, which was introduced as the Voluntary Disclosure Program (PPS). This program refers to the Tax Harmonization Law Number 7 of 2021. Although the results obtained during the tax amnesty volume, I did not meet the target, in 2022 the government still plans to implement the tax amnesty volume II. For this reason, it is necessary to analyze the difference between the tax amnesty volume I and the tax amnesty volume II (PPS), as well as predict its effectiveness if this tax amnesty will be implemented later. This study method focuses on a comparative qualitative descriptive method in which data collection is carried out by taking from the library, website, law and articles discussing this tax amnesty. The results obtained are that there are fundamental differences between tax amnesty I and tax amnesty II. The differences are found in the data, rates, and tax subjects. For taxpayers who have participated in the 2016 tax amnesty volume I, the tariff charged is cheaper than those who do not participate in the first volume I tax amnesty and there are restrictions on subjects who may participate in the second tax amnesty. The effectiveness of this second volume of tax amnesty is predicted to be successful with a record that socialization must be maximal, there is no perception that the tax amnesty endangers honest taxpayers, and the view of taxpayers that this tax amnesty is the last tax amnesty so that there is a fear of not paying taxes and being subject to fines.

Keywords: tax amnesty, Tax Harmonization Law, Voluntary Disclosure Program (PPS)

\section{PENDAHULUAN}

Pemberlakuan Tax amnesty ini tidak lepas dari pro dan kontra. Pro sosialisasi kebijakan amnesty pajak mengharapkan dengan masuknya dana Tax amnesty maka akan (1) meningkatkan stabilitas ekonomi seperti nilai rupiah yang terus menguat dan surplus cadangan devisa, sehingga pemerintah mampu membiayai berbagai macam kebutuhan Negara; (2) meningkatnya investasi di sector properti, Sektor properti akan meningkat tajam. Sebagian investor yang tadinya enggan berinvestasi properti di Indonesia karena menganggap pajak investasi properti cukup tinggi, nantinya akan berlomba-lomba membeli properti karena 
pemerintah memberikan keringanan. (3) bercermin dari keberhasilan Negara lain, bahwa 4 (empat) negara seperti Afrika Selatan, Brazil, India, dan Italia berhasil bangkit dari keterpurukan ekonomi setelah menerapkan kebijakan tax amnesty. Maka muncul harapan bahwa Indonesia akan mencapai hal serupa setelah diberlakukannya kebijakan ini. Tetapi kontra sosialisasi kebijakan amnesty pajak menganggap dengan adanya Tax amnesty ini muncul (1) adanya rasa ketidakadilan terhadap masyarakat kecil, karena masyarakat mampu tidak harus membayar pajak sektor yang sebelumnya pernah disembunyikan ; (2) adanya pandangan bahwa pemerintah telah mulai putus asa dalam penarikan pajak sehingga meminta warga untuk membayar pajak.

Bercermin pada tax amnesty jilid I yang belum maksimal dalam memperoleh pajak dari masyarakat, dengan adanya beberapa kendala yang dihadapi seperti kurangnya sosialisasi pada tax amnestyjilid I hal ini telah dirangkum dari hasil survey yang dilakukan oleh Survei Mujani Research and Consulting (SMRC) yang mengungkapkan bahwa 70\% dari responden tidak mengetahui tentang tax amnesty hal ini dapat ditarik kesimpulan bahwa tax amnesty belum menyasar seluruh bagian masyarakat, hal ini dapat menjadi evaluasi dalam penerapan tax amnestyjilid II (Safri, 2021).

Beberapa penelitian yang telah membahas tentang efektivitas pelaksanaan tax amnesty antara lain (Kartika et al., 2017) dengan hasil riset menunjukkan bahwa penerapan Tax amnesty di kota manado untuk periode I mendapatkan hasil yang memuaskan, namun untuk periode selanjutnya terjadi penurunan yang sangat signifikan hal ini terjadi karena belum maksimalnya sosialisasi serta minimnya inovasi mengenai kebijakan tax amnesty kepada masyarakat. Penelitian di tahun yang sama namun pada lokasi yang berbeda yaitu di Bitung dilakukan oleh (Awaeh \& Lambey, 2017) menyebutkan bahwa pada periode I tax amnesty pajak dikatakan berhasil namun terjadi penurunan signifikan pada periode tax amnesty selanjutnya, maka kategori pencapaian tax amnesty dikatakan tidak maksimal.

Selanjutnya (Permana, 2020) menyebutkan bahwa secara general pelaksanaan tax amnesty dapat digolongkan pada kategori berhasil karena mampu menghimpun uang mencapai Rp 135 triliun. Jumlah ini merupakan jumlah penerimaan tax manesty terbanyak di dunia apabila disandingkan dengan negara lain. Apabila ditinjau dari beberapa kondisi diantaranya target penerimaan secara deklarasi maka tax amnesty dapat dikatakan berhasil karena target sebesar Rp 4.000 triliun sedangkan pencapaian sebesar Rp 4.734 triliun; pada kondisi uang tebusan tax amnesti dianggap gagal karena target Rp 165 triluin namun yang diperoleh hanya Rp 135 triliun; pada kondisi repatriasi juga dikatakan gagal karena target sebesar Rp 1.000 Triliun hanya memperoleh sangat minim yaitu Rp 147 triliun. Meskipun demikian secara general tax amnesty dapat dikatakan berhasil karena Indonesia merupakan negara tersukses yang mampu menarik pajak paling terbesar di dunia dan mampu menaikkan tax ratio tahun 2017.

Banyak negara yang telah melakukan tax amnesty bukan hanya Indonesia saja bahkan negara-negara maju juga melakukan hal yang sama. Untuk melakukan tax amnesty jilid II bukanlah sesuatu yang tidak dapat dilakukan, negara-negara lain juga pernah melakukannya meskipun secara prinsip tax amnesty itu hanya dilakukan 1 kali selama hidup. Keberhasilan meraup dana yang lumayan besar dari tax amnesty jilid I dengan partisipasi wajib pajak hanya $2,4 \%$ pajak yang terdaftar pada tahun 2017. Kenyataan ini memberikan gambaran bahwa beberapa tahun setelah dilaksakannya tax amnesty tingkat kepatuhan wajib pajak tidak berubah signifikan dibanding tahun sebelumnya. Berdasarkan data yang diterima pada tahun 2019 menunjukkan rasio kepatuhan wajib pajak hanya berkisar diangka $70 \%$ yang masih jauh dari standar yang ditetapkan OECD yaitu tingkat kepatuhan 85\% (Suwiknyo, 2019). 
Masih sangat minimnya angka kepatuhan wajib pajak membuat pemerintah dibawah kendali Menteri keuangan mengkaji ulang tentang kelanjutan tax amnesty apakah perlu diadakan Kembali. Selain pertimbangan tentang angka kepatuhan wajib pajak, ada kondisi lain yang menjadi perhatian yaitu adanya wabah pandemic covid yang menyebabkan penerimaan pajak saat ini dibawah target. Dan hal lain juga yang menjadi pertimbangan adalah tax amnesty merupakan contoh buruk bagi para wajib pajak yang patuh serta melukai rasa keadilan.

Pada tahun 2021 dengan pertimbangan pertumbuhan ekonomi yang semakin menurun setelah diterjang badai covid 19 maka Undang-Undang Harmonisasi Peraturan Perpajakan (RUU HPP) di sahkan menjadi Undang-Undang (UU) Nomor 7 Tahun 2021 pada tanggal 29 Oktober 2021. Salah satu isi dari UU ini adalah mengatur tentang Program Pengungkapan Sukarela (PPS) atau tax amnesty jilid II. Dengan adanya UU ini diharapkan akan mampu memulihkan ekonomi dengan titik fokus perbaikan defisit anggaran serta meningkatkan rasio pajak yang tidak lain dengan cara menerapkan kebijakan peningkatan kinerja penerimaan pajak, melakukan reformasi administrasi perpajakan, menciptakan sistem perpajakan dengan prinsip keadilan dan kepastian hukum yang lebih baik, serta meningkatkan kepatuhan wajib pajak secara sukarela. Perubahan Undang-Undang Harmonisasi Peraturan Perpajakan akan berlaku mulai tahun pajak 2022. Kebijakan tax amnesty jlid II yang dikenalkan dengan nama program pengungkapan sukarela (PPS) akan berlaku pada 1 januari 2022 hingga 30 juni 2022. (Kemenkeu.go.id, 2021).

Dalam riset ini peneliti ingin mengetahui skema tax amnesty jilid II kemudian membandingkannya dengan skema tax amanesty jilid I selanjutnya dianalisis untuk melihat prediksi keefektifannya.

\section{LITERATUR REVIEW}

Pajak berdasarkan undang-undang ketentuan umum dan cara perpajakan adalah kontribusi yang wajib pada negara yang dibebankan kepada orang pribadi ataupun badan yang dilakukan secara memaksa yang dilandaskan pada undang-undang tanpa mendapatkan imbalan secara langsung serta digunakan untuk kemaslahatan masyarakat Indonesia (Thian, 2021). Sedangkan Pengampunan Pajak /tax amnesty mengacu pada UU pajak No. 11 tahun 2016 merupakan pemutihan pajak yang sudah seharusnya dibayarkan dengan jalan mengungkapkan harta dan membayar uang tebusan. Oleh karenanya wajib pajak hanya perlu untuk mengutarakan harta seta membayar uang tebusan sebagai pajak pengampunan atas harta yang selama ini tidak diungkapkan. Tujuan pemutihan pajak disebutkan dalam pasal 2 ayat 2 Undang-undang pengampunan pajak yaitu:

1. Mempercepat pengembangan dan pembangunan kembali keuangan melalui pemindahan harta, yang mengakibatkan adanya perluasan likuiditas lokal, peningkatan skala konversi rupiah, biaya pinjaman yang lebih rendah, dan usaha yang diperluas;

2. Memberdayakan perubahan perpajakan menuju skema penilaian yang lebih berkeadilan serta memiliki basis data perpajakan yang valid, menyatu dan menyeluruh.

3. Kenaikan pajak pendapatan, yang antara lain akan digunakan untuk pembiayaan kemajuan masyarakat.

Setiap pelanggar pajak akan mendapatkan sanksi. Sanksi merupakan ketentuan perundang-undangan yang dilanggar sehingga menimbulkan kewajiban berupa jaminan. menekankan defenisi di atas maka sanksi pajak merupakan sebuat alat yang digunakan untuk mencegah wajib pajak agar tidak melanggar norma-norma perpajakan (Mardiasmo, 2016). Pada Undang-undang sanksi pajak di bagi menjadi dua yaitu sanksi Administrasi dan sanksi Pidana. Sanksi administratif dapat berupa denda, bunga serta kenaikan dan dibebankan sesuai 
dengan ukuran pelanggaran atau kesalahan yang dilakukan oleh pihak-pihak tersebut. Sedangkan sanksi pidana berupa denda pidana, pidana penjara dibebankan sesuai dengan tindak pelanggaran dan tindak kejahatan yang dilakukan pihak-pihak tersebut (Konsultanpajaksurabaya.com, 2020).

Amnesti pajak sendiri dapat menjadi alat kebijakan pajak yang berguna ketika dieksploitasi dengan baik. Amnesti juga dapat digunakan secara sistematis sebagai mekanisme diskriminatif untuk meningkatkan efisiensi atau bahkan pemerataan sistem perpajakan, tetapi hanya jika komitmen pemerintah untuk menegakkan undang-undang perpajakan dapat dipercaya. Jika kredibilitas seperti itu kurang, amnesti sebenarnya dapat merusak pajak di masa depan pendapatan dengan melanggar kontrak psikologis implisit antara pembayar pajak dan negara, dengan demikian mengurangi motivasi internal wajib pajak untuk kepatuhan. Amnesti juga memiliki kepentingan politik. Implikasinya, karena amnesty dapat menjadi penanda inkonsistensi antar waktu dalam pengambilan keputusan pemerintah dan mungkin terkait dengan siklus bisnis politik. Amnesti menanggapi eksternalitas antar negara atau lapisan pemerintah yang berasal dari kebijakan pajak dan penegakan, dan efek sistem di dalamnya dapat memicu gelombang amnesti (Marchese, 2014).

\section{METODE}

Metode kajian ini berfokus secara deskriptif kualitatif dengan menggunakan metode komparatif. Metode ini digunakan untuk membandingkan dua fenomena atau lebih. Penelitian komparatif akan menemukan persamaan-persamaan dan perbedaan-perbedaan tentang benda, orang, prosedur kerja, ide, kritik terhadap orang, kelompok, terhadap suatu ide atau suatu prosedur kerja (Arikunto, 2006). Pengumpulan data dilakukan dengan cara mengambil dari Pustaka, website, UU dan artikel-artikel yang membahas seputar tax amnesty ini.

\section{HASIL}

Mengacu pada hasil tax amnesty jilid 1 yang telah dideklarasikan oleh Menteri keuangan Sri Mulayani, menyatakan bahwa tax amnestytersebut berhasil menghimpun dana sebesar:

Tabel 1. Pencapaian Tax amnestyJilid I

\begin{tabular}{|l|l|l|c|}
\hline & \multicolumn{1}{|c|}{ Target } & \multicolumn{1}{c|}{ Realisasi } & \multicolumn{1}{c|}{$\begin{array}{c}\text { Persentase } \\
\text { Keberhasilan }\end{array}$} \\
\hline Deklarasi harta & $\mathrm{Rp} \mathrm{4.000} \mathrm{Triliun}$ & $\mathrm{Rp} \mathrm{4.813,4} \mathrm{triliun}$ & $120,3 \%$ \\
\hline Uang tebusan & $\mathrm{Rp} \mathrm{165} \mathrm{triliun}$ & $\mathrm{Rp} \mathrm{130} \mathrm{Triliun}$ & $78,79 \%$ \\
\hline Repatriasi & $\mathrm{Rp} \mathrm{1.000} \mathrm{triliun}$ & $\mathrm{Rp} \mathrm{146} \mathrm{triliun}$ & $14,6 \%$ \\
\hline
\end{tabular}

Sumber: https://www.kominfo.go.id/content/detail/9520/realisasi-tax-amnesty-deklarasi-rp48134-triliun-danrepatriasi-rp146-triliun/0/berita (2017)

Mengambil data dari Direktorat Jenderal Pajak Kementerian Keuangan melalui laman media Indonesia.com (Nua, 2019) jumlah wajib pajak yang mengikuti tax amnesty jilid I sebanyak 974.058 wajib pajak. Dari jumlah tersebut deklarasi harta yang ditargetkan sebanyak Rp 4.000 triliun, hasil dilapangan ternyata telah melebihi targetnya yaitu sebesar Rp 4.813,4 Triliun (120,3\%). Jumlah ini didapatkan dari dua jalur deklarasi yaitu

a. Deklarasi harta didalam negeri sebesar Rp 3.633,1 Triliun

b. Deklarasi harta luar negeri Rp 1.180,3 triliun

Selanjutnya tax amnesty dari uang tebusan ditargetkan sebesar Rp 165 triliun, didapati dilapangan tidak mencapai target. Uang tebusan hanya dapat diperoleh dengan jumlah total Rp 130 Triliun. Jumlah ini dihasilkan dari: 
a. Wajib pajak orang pribadi non UMKM sebesar Rp 90,36 triliun

b. Wajib pajak Orang pribadi UMK Rp 7,56 Triliun

c. Wajib pajak badan non UMKM sebesar Rp 4,31 Triliun

d. Wajib pajak badan UKM Rp 0,62 triliun.

Kemudian melalui jalur repatriasi yang ditargetkan akan memperoleh dana sebesar Rp 1.000 Triliun namun kenyataan dilapangan hanya mendapatkan $\mathrm{Rp} 146$ Triliun (14,6\%) jumlah ini yang paling minim pendapatannya dibandingkan dengan dua jalur yang lainnya. Jumlah uang repatriasi ini terbagi kepada:

a. Realisasi Rp 121,3 Triluin

b. Belum masuk ke dalam negeri Rp 24,7 Triliun. Dana repatriasi yang belum masuk ini menurut Menteri keuangan disebabkan karena adanya regulasi yang sulit diterapkan dimana harta tersebut berada sehingga sulit untuk secaepatnya dana itu ditarik dan di investasikan ke Indonesia. Alasan lain dan tersebut belum masuk ke Indonesia karena dana yang dilaporkan tersebut bukanlah dana Likuid, sehingga haruslah terlebih dahulu dicairkan menjadi uang tunai. Ada juga alasan lainnya yaitu masih menunggu jatuh tempo karena berbentuk deposito (kominfo.go.id, 2017).

Pemberlakuan tax amnesty jilid pertama memiliki skema tarif pengampunan pajak adalah sebagai berikut:

Tabel 2 Skema Tarif pengampunan pajak tax amnestyjilid I

\begin{tabular}{|c|c|c|c|}
\hline & $\begin{array}{c}\text { Periode I } \\
\text { 1Juli -30September2016 }\end{array}$ & $\begin{array}{c}\text { Periode II } \\
\text { 1Oktober-31Desember } 2016\end{array}$ & $\begin{array}{l}\text { Periode III } \\
\text { 1Januari-31maret2017 }\end{array}$ \\
\hline $\begin{array}{l}\text { Harta yang berada } \\
\text { didalam negeri atau luar } \\
\text { negeri diinvestasikan di } \\
\text { Indonesia selama tiga } \\
\text { tahun }\end{array}$ & Tarif $2 \%$ & Tarif $3 \%$ & Tarif 5\% \\
\hline $\begin{array}{l}\text { Harta yang berada di luar } \\
\text { negeri tidak dialihkan ke } \\
\text { dalam negeri }\end{array}$ & Tarif $4 \%$ & Tarif $6 \%$ & Tarif $10 \%$ \\
\hline Wajib Pajak UMKM & \multicolumn{3}{|c|}{$\begin{array}{l}\text { - Mengungkapkan nilai harta dari 4,8 milyar sampai dengan Rp } 10 \text { milyar } \\
\text { dalam surat pernyataan dikenai tarif } 0,5 \% \\
\text { Mengungkapkan nilai harta lebih dari } 10 \text { milyar dalam surat pernyataan } \\
\text { untuk periode bulan pertama sampai } 31 \text { maret } 2017 \text {, dikenai tarif } 2 \%\end{array}$} \\
\hline
\end{tabular}

Sumber: (ZRF, 2016)

Subjek pajak pada tax amnesty jilid pertama merupakan wajib pajak orang pribadi dan wajib pajak badan usaha yang mempunyai keharusan untuk menyampaikan SPT tahunan dikecualikan bagi wajib pajak yang sedang dalam penyelidikan ataupun proses pengadilan serta sedang menjalani hukuman bidang pajak. Dikhususkan bagi Orang pribadi misalnya petani, nelayan, pensiunan, tenaga kerja Indonesia atau subjek pajak warisan yang belum terbagi, yang jumlah penghasilannya pada Tahun Pajak Terakhir di bawah PTKP boleh tidak menggunakan haknya untuk mengikuti Pengampunan Pajak tertera pada Pasal 1 ayat (2) PER-11/PJ/2016. Kemudian bagi Warga Negara Indonesia yang tidak bertempat tinggal di Indonesia lebih dari 183 (seratus delapan puluh tiga) hari dalam jangka waktu 12 (dua belas) bulan dan tidak mempunyai penghasilan dari Indonesia merupakan Subjek Pajak Luar Negeri dan boleh tidak menggunakan haknya untuk mengikuti Pengampunan Pajak sesuai dengan Pasal 1 ayat (3) PER-11/PJ/2016. Dalam hal Wajib Pajak yang tidak menggunakan haknya untuk mengikuti Pengampunan Pajak, ketentuan sebagaimana dimaksud dalam Pasal 18 ayat (2) UU Nomor 11 TAHUN 2016 yang menyatakan bahwa : (Dalam hal Wajib Pajak tidak menyampaikan Surat Pernyataan sampai dengan periode Pengampunan Pajak berakhir; dan Direktur Jenderal Pajak 
menemukan data dan/atau informasi mengenai Harta Wajib Pajak yang diperoleh sejak tanggal 1 Januari 1985 sampai dengan 31 Desember 2015 dan belum dilaporkan dalam SPT Tahunan $\mathrm{PPh}$, atas Harta dimaksud dianggap sebagai tambahan penghasilan yang diterima atau diperoleh Wajib Pajak pada saat ditemukannya data dan/atau informasi mengenai Harta dimaksud, paling lama 3 (tiga) tahun terhitung sejak Undang-Undang ini mulai berlaku) menjadi tidak diterapkan sesuai dengan Pasal 1 ayat (4) PER-11/PJ/2016.

Objek pajak pada tax amnesty jilid 1 merupakan kewajiban perpajakan yang belum ataupun belum sepenuhnya diselesaikan oleh wajib pajak, yang terepresentasi dalam harta yang belum pernah dilaporkan dalam SPT Tahunan PPh Terakhir. Pengampunan Pajak ini diberikan kepada Wajib Pajak melalui pengungkapan Harta yang dimilikinya dalam Surat Pernyataan (pajak.go.id, 2016).

Tax amnesty jilid II mengacu kepada Undang-undang Harmonisasi Peraturan perpajakan (UU HPP) yang salah satunya membahas tentang program pengungkapan sukarela/PPS (tax amnestyjilid II). Program Pengungkapan Sukarela/PPS atau Tax amnestyyaitu pemberian kesempatan kepada Wajib Pajak untuk melaporkan atau mengungkapkan kewajiban perpajakan yang belum dipenuhi secara sukarela melalui Pembayaran Pajak Penghasilan berdasarkan pengungkapan harta yang tidak atau belum sepenuhnya dilaporkan oleh peserta program Pengampunan Pajak serta pembayaran Pajak Penghasilan berdasarkan pengungkapan harta yang belum dilaporkan dalam SPT Tahunan PPh Tahun Pajak 2020. Rencana penerapan tax amnesty jilid dua ini akan dilaksanakan pada awal januari 2022 hingga 30 juni 2022 yaitu selama enam bulan.

Terdapat dua kebijakan dalam tax amnesty jilid II ini yaitu:

a. Kebijakan pertama

Ditinjau dari subjek pajaknya merupakan wajib pajak orang pribadi maupun wajib pajak badan yang sebelumnya menjadi peserta wajib pajak Tax amnesty jilid I dengan basis asset dari 1 januari 1985 sampai 31 desember 2015 dengan catatan pada saat tax amnesty jilid I kurang atau belum diungkapkan. Adapun yang dapat diperoleh oleh peserta dalam tax amnesty ini adalah perserta memperoleh tarif $\mathrm{PPh}$ final rendah apabila Sebagian besar hartanya diinvestasikan dalam SBN/hilirisasi/renewable energi. Dengan rincian sebagai berikut:

Tabel 3. Skema tax amnestyjilid II menggunakan kebijakan pertama

\begin{tabular}{|c|c|c|}
\hline $\begin{array}{c}\text { Untuk asset LN repatriasi dan } \\
\text { asset dalam Negeri }\end{array}$ & Untuk deklarasi Luar Negeri & $\begin{array}{c}\text { Untuk asset LN repatriasi dan } \\
\text { asset dalam negeri yang } \\
\text { diinvestasikan dalam } \\
\text { SBN/hilirisasi/renewable energi }\end{array}$ \\
\hline $8 \%$ & $11 \%$ & $6 \%$ \\
\hline
\end{tabular}

Sumber: (Putri, 2021)

b. Kebijakan kedua

Ditinjau dari subjek pajaknya merupakan wajib pajak orang pribadi dengan basis asset perolehan 1 januari 2016 sampai 31 desember 2020 yang kurang atau belum dilaporkan dalam SPT tahunan 2020. Adapun yang dapat diperoleh oleh peserta wajib pajak pph final rendaha apabila Sebagian hartanya diinvestasikan dalam SBN/hilirisasi/renewable energi. Dengan rincian sebagai berikut:

Tabel 4. Skema tax amnesty jilid II menggunakan kebijakan Kedua 
Owner: Riset \& Jurnal Akuntansi

e-ISSN : 2548-9224 |p-ISSN : 2548-7507

Volume 5 Nomor 2, Agustus 2021

DOI : https://doi.org/10.33395/owner.v5i2.565

\begin{tabular}{|c|c|c|}
\hline $\begin{array}{c}\text { Untuk asset LN repatriasi dan } \\
\text { asset dalam Negeri }\end{array}$ & Untuk deklarasi Luar Negeri & $\begin{array}{c}\text { Untuk asset LN repatriasi dan } \\
\text { asset dalam negeri yang } \\
\text { diinvestasikan dalam } \\
\text { SBN/hilirisasi/renewable energi }\end{array}$ \\
\hline $14 \%$ & $18 \%$ & $12 \%$ \\
\hline
\end{tabular}

Sumber: (Putri, 2021)

Peserta wajib pajak dapat menyampaikan harta bersih yang belum atau kurang di sampaikan dalam surat pernyataan apabila direktorat jendral pajak belum menemukan data dan informasi tentang harta dimaksud sesuai dengan Pasal 37 B ayat 1 Draf RUU KUP (Victoria, 2021). Untuk lebih jelasnya dapat digambaran pada tabel peraturan program pengungkapan sukarela/PPs atau tax amnestyjilid 2 berikut ini:

Tabel 5. Peraturan pelaksanaan Program pengungkapan Sukarela/PPS atau tax amnesty jilid II

\begin{tabular}{|c|c|c|}
\hline Kebijakan pertama & Kebijakan kedua & Keterangan \\
\hline $\begin{array}{l}\text { Wajib pajak orang } \\
\text { pribadi/badan yang pernah } \\
\text { mengikuti tax } \text { amnesty jilid I }\end{array}$ & Wajib pajak orang Pribadi & Subjek Pajak \\
\hline $\begin{array}{l}\text { Asset } 1 \text { januari } 1985 \text { sampai } \\
31 \text { desember } 2015 \text { dengan } \\
\text { catatan pada saat tax amnesty } \\
\text { jilid I kurang atau belum } \\
\text { diungkapkan }\end{array}$ & $\begin{array}{l}\text { Aset januari } 2016 \text { sampai } 31 \\
\text { desember } 2020 \text { yang kurang } \\
\text { atau belum dilaporkan dalam } \\
\text { SPT tahunan } 2020\end{array}$ & Asal Aset \\
\hline $11 \%$ deklarasi LN & $18 \%$ deklarasi LN & \\
\hline $\begin{array}{l}8 \% \text { asset } \mathrm{LN} \text { repatriasi dan } \\
\text { asset DN }\end{array}$ & $\begin{array}{l}14 \% \text { asset } \mathrm{LN} \text { repatriasi dan } \\
\text { asset DN }\end{array}$ & \\
\hline $\begin{array}{l}6 \% \text { asset LN repatriasi dan } \\
\text { asset DN yang hartanya } \\
\text { diinvestasikan dalam } \\
\text { SBN/hilirisasi/renewable } \\
\text { energi }\end{array}$ & $\begin{array}{l}\text { 12\% asset LN repatriasi dan } \\
\text { asset DN yang hartanya } \\
\text { diinvestasikan dalam } \\
\text { SBN/hilirisasi/renewable } \\
\text { energi }\end{array}$ & Tarif PPh \\
\hline
\end{tabular}

Sumber: dirangkum oleh peneliti dari berbagai sumber (2021)

\section{Pembahasan penelitian}

\section{Perbedaan Mendasar tax amnesty Jilid I dan Jilid II}

Perbedaan mencolok antara tax amnesty jilid I dan tax amnesty jilid II yang pertama adalah dari subjek pajaknya. Jika pada pada tax amnesty jilid I semua wajib pajak boleh mengikuti tax amnesty kecuali yang telah dikecualikan karena hal tetentu. Pada tax amnesty jilid II tidak semua wajib pajak boleh mengikutinya hanya wajib pajak yang pernah mengikuti tax amnesty jilid I boleh mengikuti tax amnesty jilid II dengan menggunakan kebijakan pertama. Sedangkan untuk kebijakan kedua hanya wajib pajak perorangan yang boleh mengikutinya sedangkan wajib pajak badan tidak diperkenankan untuk mengikutinya.

Yang kedua adalah dari segi tarif yang ditawarkan untuk tarif tax amnesty jilid 2 ini lebih tinggi dari pada tarif tax amnesty jilid I baik untuk periode satu hingga periode tiga. Untuk tax amnesty jilid I, paling tinggi adalah $10 \%$ yang dilaksanakan pada periode tiga yaitu 1 januari 2017 hingga 31 maret 2017. Sedangkan tarif pada tax amnesty jilid dua tertinggi adalah $18 \%$ untuk deklarasi Luar negeri pada penerapan kebjiakan II. 


\section{Peluang keberhasilan Tax amnestyJilid II}

Dengan selesainya tax amnesty jilid I diperoleh beberapa keberhasilan dan kelemahan yang akan menjadi dasar untuk pelaksanaan tax amnesty jilid II diantaranya adalah pemerintah mendapatkan database data perpajakan yang akan dapat dijadikan basis data pajak yang lebih akurat karena dengan adanya basis data maka pihak pajak dapat memantau dana pajak yang dapat ditarik. Mengambil pandangan dari Menteri keuangan Sri Mulyani bahwa basis data yang diperoleh dari amnesty pajak dapat dimanfaatkan untuk menggali potensi serta mengidentifikasi potensi pemasukan pajak dan juga menjadi dasar informasi untuk dijadikan dasar penelitian tentang perpajakan untuk tahun-tahun berikutnya (Klinikpajak.co.id, 2016).

Kolaborasi antara database data perpajakan dan kemajuan inovatif dapat menangani dan memeriksa wajib pajak yang tidak patuh. Strategi ini akan ampuh dan tepat jika otoritas publik berani mengambil tindakan tegas terhadap para penghindar pajak. Terlepas dari kenyataan bahwa ada beberapa strategi yang dianggap cocok untuk mengendalikan transaksi publik, otoritas publik sebenarnya harus tahu tentang berbagai kendala di seluruh dunia dan kemungkinan mengubah desain transaksi di kemudian hari. Perubahan dalam unsur-unsur dan inovasi yang bertanggung jawab juga harus cenderung responsif dan terarah (cnnindonesia.com, 2021).

Dalam pelaksaan Tax amnesty jilid II maka kita perlu melirik Kembali kebelakang tentang kelemahan tax amnesty jilid I dari sisi jumlah wajib pajak yang mengikuti program ini. Jumlah wajib pajak pada saat tersebut masih sangat minim dibanding dengan wajib pajak yang melapor SPT yang mencapai 20,1 juta wajib pajak. Apalagi dibandingkan dengan jumlah wajib pajak yang telah memiliki NPWP. Selain itu kegagalan berikutnya adalah penerimaan uang tebusan dan repatriasi masih jauh dari target yang telah ditentukan.

Pengesahan Undang-undang Harmonisasi Perpajakan yang salah satu pembahasan didalamnya tentang amnesty pajak menjadi suatu hal yang perlu dikaji apakah penerapan ini akan berhasil atau tidak. Seperti diketahu bersama bahwa keadaan ekonomi dunia sedang dalam goncangan, tidak terkecuali Indonesia. Wabah covid yang melanda Indonesia sejatinya telah menghancurkan sektor perekonomian. untuk memulihkan perekonomian nasional maka diwacanakan upaya-upaya strategis yaitu dengan adanya kebijakan tax amnesty. Hal ini diharapkan dapat menolong pemulihan dunia usaha selama wabah melanda

Adanya wacana dari pemerintah bahwa kegiatan tax amnesty jilid II ini lebih dimaksudkan untuk memperluas basis pajak serta upaya peningkatan kepatuhan secara sukarela untuk melaporkan kewajiban pajak yang belum dilaporkan (Jannah, 2021). Namun tidak dipungkiri juga bahwa pemerintah berharap dana yang terkumpul dari keberhasilan tax amnesty jilid II ini untuk menutupi defisit ekonomi, Beberapa pendapat yang beredar di media online tentang Tax amnesty jilid II yaitu menurut Direktur Center of Economic and Law Studies (CELIOS) Bhima Yudhistira mengatakan bahwa apabila pemerintah sering melaksanakan tax amnesty maka dapat menurunkan tingkat kepatuhan wajib pajak, selain itu wajib pajak nakal akan mengambil kesempatan berikutnya hal ini sangat bertentangan dengan komitmen pemerintah pasca tax amnesty untuk meningkatkan kepatuhan wajib pajak (Saputra, 2021). Selain itu menurut Wakil Ketua Umum Bidang Kebijakan Fiskal dan Publik Kamar Dagang dan Industri (Kadin) Suryadi mengatakan bahwa tarif PPh Final 6\% bagi yang menginvestasikan harta kekayaannya ke dalam Surat Berharga Negara (SBN) atau untuk hilirisasi sumber daya alam (SDA) dan energi terbarukan masih belum jelas tentang hilirisasi itu sendiri, menurut beliau jika orang pribadi ingin berinvestasi pada energi baru terbarukan, 
bukan melalui tax amnesty, namun dapat diperoleh melalui skema pembiayaan yang lain. Selain itu, target subjek pajak untuk tax amnesty lebih cocok diberikan untuk perusahaan (Putri, 2021).

Yang menjadi sorotan dalam tax amnesty jilid II adalah masalah sosialisasi. Menurut Ketua Umum Kamar Dagang dan Industri (Kadin) Indonesia Arsjad Rasjid mengatakan, peluang meningkatkan kepatuhan wajib pajak termasuk pengusaha masih sangat besar, maka besar atau kecilnya keikutsertaaan wajib pajak bergantung pada sosialisasi tax amnesty, oleh karenanya bercermin dari tax amnesty lalu masih banyak pengusaha yang belum berkontribusi karena kurangnya pemahaman dan pengetahuan. Maka sosialisasi merupakan kunci sukses dalam melaksanakan tax amnesty (Nurul \& Movanita, 2021)

Terkait munculnya tax amnesty jilid II, Fajry Akbar selaku pengamat memberikan penilaian serta menyampaikan pandangannya tentang kesungguhan urgensinya pengampunan pajak di Indonesia untuk diadakan kembali. Jika program pengampunan kewajiban diselesaikan lebih dari satu kali dalam waktu dekat, maka, pada saat itu, program tax amnesty tidak akan berjalan dengan sukses. Selain itu, wawasan atau kepercayaan publik terhadap otoritas publik juga akan kabur jika tax amnesty jilid II dilaksanakan dalam waktu yang dekat dari tax amnesty sebelumnya, mengingat otoritas publik telah melaksanakannya pada tahun 2016. Menurut rencananya diawal tax amnesty hanya diadakan satu kali. Kecuali jika otoritas publik memiliki pembenaran yang sangat mengesankan di balik pengaturan tax amnesty jilid II ini. Lebih lanjut, jika penilaian tax amnesty jilid II dilakukan dengan jangka waktu yang dekat, kemungkinan akan menimbulkan perasaan tidak enak bagi warga yang belakangan ini mengikuti dan berpegang teguh pada kepatuhan perpajakan dan dapat berdampak pada berkurangnya tingkat konsistensi warga terhadap perpajakan (pajakku.com, 2021).

Untuk mensukseskan kegiatan tax amnestyjilid II ini diperlukannya persepsi masyarakat/wajib pajak yang baik terhadap kegiatan ini. Menurut (Andriawan, 2019) dari hasil penelitiannya menyimpulkan bahwa wajib pajak pajak masih memiliki pandangan posistif terkait dengan pelaksanaan program tax amnesty di Buleleng.

\section{KESIMPULAN}

Terdapat perbedaan mendasar antara tax amnesty I dan tax amnesty II yaitu pada tarif yang dibebankan dimana tarif tax amnesty jilid II ini lebih tinggi dari tarif tax amnesty jilid I, kemudian subjek yang boleh mengikuti amnesty pajak. untuk yang pernah mengikuti tax amnesty jilid I tahun 2016 maka tarif yang dibebankan lebih murah dari pada yang tidak mengikuti tax amnesty jilid I hal ini dimaksudkan untuk tax amnesty jilid II pada kebijakan I. untuk kebijakan dua maka yang boleh mengikutinya hanyalah wajib pajak orang pribadi. peluang tax amnesty jilid II ini diprediksi dapat berhasil dengan catatan sosialisasi harus maksimal, tidak adanya persepsi bahwa tax amnesty membahayakan pembayar pajak yang jujur, serta adanya pandangan dari wajib pajak tax amnesty ini merupakan tax amnesti terakhir sehingga muncul rasa takut tidak membayar pajak serta terkena denda. Untuk itu diharapkan kepada pemerintah dalam melaksanakan tax amnesty harus mempertimbangkan jangka waktu antara tax amnesty sebelumnya, selain itu sosialisasi dianggap sangat penting untuk mensukseskan kegiatan tersebut, maka diharapkan pemerintah membuat perencanaan dan sosialisasi yang mumpuni demi kesuksesan tax amnesty.

\section{REFERENSI}


Andriawan, I. G. D. (2019). Persepsi Wajib Pajak Atas Program Tax Amnesty Dalam Perspektif Budaya $\begin{array}{llll}\text { Meboya. Jurnal Akuntansi, } & \text { 4(1), 66-87. }\end{array}$ https://ejournal.undiksha.ac.id/index.php/JIA/article/view/16653/10609

Arikunto, S. (2006). Prosedur Penelitian : Suatu Pendekatan Praktik (revisi VI). PT Rineka Cipta.

Awaeh, M. A., \& Lambey, L. (2017). Analisis Efektivitas Penerapan Tax Amnesty (Pengampunan Pajak) Terhadap Penerimaan Pajak Pada Kantor Pelayanan Pajak Pratama Bitung. Jurnal EMBA, 5(2), 2268-2276. file:///C:/Users/windos8/Downloads/16529-33119-1-SM.pdf

cnnindonesia.com. (2021). Wacana Tax Amnesty Jilid II Kembali Bergema. Www.Cnnindonesia.Com. https://www.cnnindonesia.com/ekonomi/202103 19175122-532-619750/wacana-tax-amnestyjilid-ii-kembali-bergema.

Jannah, S. M. (2021). RUU HPP Disahkan Jadi UU Tax Amnesty Jilid II \& Upaya Pemerintah Genjot Penerimaan Pajak. Https://Tirto.Id/. https://tirto.id/tax-amnesty-jilid-ii-upaya-pemerintah-genjotpenerimaan-pajak-gkd9

Kartika, C. A., Nangoi, G. B., \& Lambey, R. (2017). Analisis Efektivitas Penerapan Tax Amnesty (Pengampunan Pajak) Terhadap Penerimaan Pajak Dari Wajib Pajak Badan Usaha Pada Kantor Pelayanan Pajak Pratama Manado. Emba, 5(2), 945-954.

Kemenkeu.go.id. (2021). UU HPP diundangkan menjadi UU 7/2021, Perhatikan Waktu Pemberlakuannya. Www.Kemenkeu.Go.Id. https://www.kemenkeu .go.id/publikasi/berita/uuhpp-diundangkan-menjadi-uu-72021-perhatikan-waktu-pemberlakuannya/

Klinikpajak.co.id. (2016). Menkeu: Penguatan Basis Data Bermanfaat Mulai 2017. Www.Klinikpajak.Co.Id. http://www.klinikpajak.co.id/berita+detail /?id=berita+pajak++menkeu\%3A+penguatan+basis+data+bermanfaat+ mulai+2017

kominfo.go.id. (2017). Realisasi Tax Amnesty, Deklarasi Rp4.813,4 Triliun dan Repatriasi Rp146 Triliun. Www.Kominfo.Go.Id. https://www.kominfo. go.id/content/detail/9520/realisasi-taxamnesty-deklarasi-rp48134-triliun-dan-repatriasi-rp146-triliun/0/berita

Konsultanpajaksurabaya.com. (2020). Jenis-jenis Sanksi Pajak. Www.Konsultan pajaksurabaya.Com. https://konsultanpajaksurabaya.com/index.php?/jenis jenis-sanksi-pajak

Marchese, C. (2014). Tax Amnesties. SSRN Electronic Journal, 1-14. https://doi.org/10.2139/ssrn.2405812

Mardiasmo. (2016). Perpajakan (revisi). Andi.

Nua, F. (2019). Tax Amnesty tidak Perlu Ada Lagi. Https://Mediaindonesia.Com/. https://mediaindonesia.com/ekonomi/253306/tax-amnesty-tidak-perlu-ada-lagi

Nurul, F., \& Movanita. (2021). Ada Tax Amnesty, Kadin: Peluang Partisipasi Pebisnis Sangat Besar. Kompas.Com. https://money.kompas.com/read/2021 /10/15/071111226/ada-tax-amnesty-kadinpeluang-partisipasi-pebisnis-sangat-besar?page=all

pajak.go.id. (2016). Amnesti Pajak. Https://Pajak.Go.Id. https://pajak.go.id/id/ amnesti-pajak-10

pajakku.com. (2021). Menilai Kebijakan Tax Amnesty Jilid II di Indonesia. Www.Pajakku.Com. https://www.pajakku.com/read/60c87965eb01ba1922 ccae51/Menilai-Kebijakan-Tax-Amnesty-Jilid-II-di-Indonesia

Permana, R. K. (2020). Efektivitas, Dampak, Dan Keberhasilan Tax Amnesty Di Indonesia. Jurnal Akuntansi Dan Bisnis Krisnadwipayana, 7(3), 95-102. file:///C:/Users/windos8/Downloads/4502912-1-PB(1).pdf

Putri, C. A. (2021). Pengusaha Galau! Mau Ikut Tax Amnesty II Tapi Tetap Diperiksa. Www.Cnbcindonesia.Com. https://www.cnbcindonesia.com /news/20211102104926-4288340/pengusaha-galau-mau-ikut-tax-amnesty-ii-tapi-tetap-diperiksa

Safri. (2021). Efektiftas Program Tax amnesty jilid II dan Faktor Keberhasilan dan Permasalahan: Pelajaran dari Tax amnesty Jilid I. Jurnal Mitra Manajemen, 12(2), 11-22. https://journal.universitassuryadarma.ac.id/ index.php/jmm/article/view/743/726

Saputra, D. (2021). RUU KUP Buka Peluang Tax Amnesty Jilid II, Ekonom Ingatkan Kepercayaan Wajib Pajak Bisa https://ekonomi.bisnis.com/read/20210823/259/1432947/ruu-kup-buka-peluang-tax-amnestyjilid-ii-ekonom-ingatkan-kepercayaan-wajib-pajak-bisa-turun. 
Owner: Riset \& Jurnal Akuntansi

e-ISSN : 2548-9224 | p-ISSN : 2548-7507

Volume 5 Nomor 2, Agustus 2021

DOI : https://doi.org/10.33395/owner.v5i2.565

Suwiknyo, E. (2019). Tax Amnesty, Reformasi Pajak yang Tak Usai. Bisnis.Com. https://ekonomi.bisnis.com/read/20191017/259/1160343/tax-amnesty-reformasi-pajak-yang-takusai.

Thian, A. (2021). Dasar-Dasar Perpajakan (T. A. Prabawati (ed.)). Andi.

Victoria, A. O. (2021). Tax Amnesty Jilid Kedua, Apa Beda dengan yang Pertama?". Katadata.Co.Id.

ZRF, A. A. (2016). Ini Dia Daftar Tarif Tax Amnesty. Pengampunanpajak.Com. https://pengampunanpajak.com/2016/06/30/ini-dia-daftar-tarif-tax-amnesty/ 